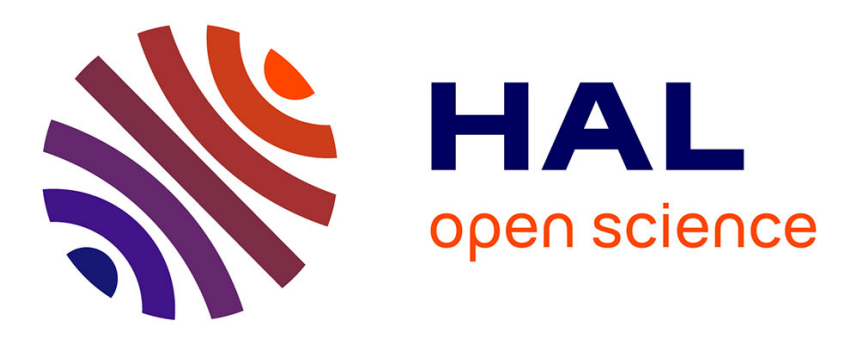

\title{
Selective modification of a native protein in a patient tissue homogenate using palladium nanoparticles
}

Arnaud Peramo, Anaëlle Dumas, Hynd Remita, Mireille Benoît, Stephanie

Yen-Nicolay, Raphaël Corre, Ruy A Louzada, Corinne Dupuy, Shannon

Pecnard, Benoit Lambert, et al.

\section{To cite this version:}

Arnaud Peramo, Anaëlle Dumas, Hynd Remita, Mireille Benoît, Stephanie Yen-Nicolay, et al.. Selective modification of a native protein in a patient tissue homogenate using palladium nanoparticles. Chemical Communications, 2019, 55, pp.15121 - 15124. 10.1039/c9cc07803g * hal-03009700

\section{HAL Id: hal-03009700 https://hal.science/hal-03009700}

Submitted on 2 Dec 2020

HAL is a multi-disciplinary open access archive for the deposit and dissemination of scientific research documents, whether they are published or not. The documents may come from teaching and research institutions in France or abroad, or from public or private research centers.
L'archive ouverte pluridisciplinaire HAL, est destinée au dépôt et à la diffusion de documents scientifiques de niveau recherche, publiés ou non, émanant des établissements d'enseignement et de recherche français ou étrangers, des laboratoires publics ou privés. 


\section{Selective modification of a native protein in a patient tissue homogenate using palladium nanoparticles}

Received 00th January 20xx, Accepted 00th January 20xx

DOI: $10.1039 / x 0 x x 00000 x$

\author{
Arnaud Peramo, ${ }^{a}$ Anaëlle Dumas, ${ }^{a}$ Hynd Remita, ${ }^{b}$ Mireille Benoît, ${ }^{b}$ Stephanie Yen-Nicolay, ${ }^{c}$ \\ Raphaël Corre, ${ }^{d}$ Ruy A. Louzada, ${ }^{d}$ Corinne Dupuy, ${ }^{d}$ Shanon Pecnard, ${ }^{a}$ Benoit Lambert, ${ }^{e}$ Jacques \\ Young, ${ }^{e}$ Didier Desmaële ${ }^{a}$ and Patrick Couvreur* ${ }^{a}$
}

We have developed new benign palladium nanoparticles able to catalyze the Suzuki-Miyaura cross-coupling reaction on human thyroglobulin $(\mathrm{Tg})$, a naturally iodinated protein produced by the thyroid gland, in homogenates from patients' tissues. This represents the first example of a chemoselective native protein modification using transition metal nanoobjects in near-organ medium.

The selective functionalization of proteins with a chemical reporter inside complex biological media has been the subject of intensive studies during the last decade for investigating the dynamics and function of biomolecules. ${ }^{1,2}$ This approach usually involves the genetic or metabolic incorporation of a small organic reporter carrying a bio-orthogonal reactive group into a target protein within the cell. The modification of the resulting tagged protein may then be achieved through a selective reaction using an exogenous probe. The identification of a selective reaction using a non-perturbing and cell permeable chemical handle that is inert towards other cellular components and will react rapidly with its partners under physiological conditions represents the main challenge of this approach. ${ }^{3}$ As a result, only few chemical reactions fulfilling all these criteria have been developed. Among them, the Cu-catalyzed alkyne-azide cycloaddition has become one of the most commonly used bioorthogonal conjugation reaction. ${ }^{4,5}$ However, the cytotoxicity of $\mathrm{Cu}$ ions has limited the use of this reaction in living systems. ${ }^{6}$ As an alternative, copper-free versions of this ligation involving strained alkynes were developed but they showed specificity problems. ${ }^{7}$ Many other approaches were proposed

\footnotetext{
a. Institut Galien Paris-Sud, UMR 8612, CNRS Univ. Paris-Sud, Université ParisSaclay, Faculté de Pharmacie 5 rue Jean-Baptiste Clément, 92290 ChatenayMalabry, France.

b. Laboratoire de Chimie Physique, UMR 8000-CNRS, Bâtiment 349, Université ParisSud, Université Paris-Saclay, Rue Michel Magat, 91400 Orsay 91405 Orsay, France.

c. Trans-Prot, UMS IPSIT, Univ. Paris-Sud, Université Paris-Saclay, Faculté de Pharmacie 5 rue JB Clément, 92296 Châtenay-Malabry, France.

d. Institut de Cancérologie Gustave Roussy, UMR8200 CNRS, 114 rue Edouard Vaillant, 94805 Villejuif, France

e. Hôpital Bicêtre, 78 rue du Général Leclerc 94270 Le Kremlin-Bicêtre, France

† Electronic supplementary information (ESI) available: Full experimental and spectroscopic data.. See DOI: 10.1039/x0xx00000x
}

including Staudinger ligation, ${ }^{8}$ hydrazine and oxime ligation ${ }^{9}$ and more recently the inverse-electron demand Diels-Alder ${ }^{10}$ reactions between tetrazines and trans-cyclooctenes ${ }^{11}$ or vinylboronic acid. ${ }^{12}$ Transition metal-mediated reactions that involve reactive chemical groups not found in natural systems provide also fascinating possibilities for the selective in vivo chemical manipulation of proteins. ${ }^{13,14}$ Gold $^{15,16}$ and ruthenium ${ }^{17}$ have been used for the selective uncaging of fluorescent probes but, palladium appeared as one of the most promising metals, giving rise to numerous applications in biology including in vivo prodrug activation or intracellular labelling. ${ }^{18-20}$

Recently, site-specific protein derivatization by Suzuki-Miyaura reaction of genetically encoded $p$-iodophenylalanine (pIPhe) was demonstrated using a water-soluble palladium catalyst both in vitro ${ }^{21}$ and in living bacterial cells. ${ }^{22}$ Nevertheless, the need to use a high concentration of palladium, probably to surmount the nonspecific sequestration of the metal by surrounding biomolecules, could hamper further in vivo applications. This issue could be overcome to some extent by using nanoformulations of palladium which were reported to allow cross-coupling reactions in living mammalian cells, thanks to their ability to cross the cell membrane hence improving palladium cellular uptake. ${ }^{23}$ Despite these influential advances, palladium nanoparticles have never been used to modify a natural protein with direct therapeutic potential. In this study, we provide the first example of covalent modification of human thyroglobulin $(\mathrm{Tg})$, an iodinated native protein, involved in the pathogenesis and the progression of the Graves's disease or in the metastatic papillary thyroid carcinoma. Indeed, using SuzukiMiyaura cross-coupling reaction catalyzed by palladium nanoparticles (Pd NPs), we made the first proof of concept that a target native protein may be chemically altered, directly in a patient tissue homogenate. This brings the use of bioorthogonal reactions a step ahead, closer to possible biomedical applications.

To harness the unique reactivity of palladium while preserving its biocompatibility we first explored the reactivity of small palladium nanoparticles entrapped into larger polymeric nanoparticles of poly(lactic-co-glycolic acid)-polyethyleneglycol, ${ }^{24}$ a material which demonstrated clinical safety. ${ }^{25}$ However, long-term stability concerns of this formulation compelled us to search for a more 


\section{COMMUNICATION}

robust catalyst. We then investigated the palladium urchin-like nanostructures (Pd-Urchin NPs) developed by Ksar F. et $a l,{ }^{26}$ assuming that their 3D porous morphology would offer a large surface area embedding high catalytic activity. The Pd-Urchin NPs were obtained by slow reduction of $\left(\mathrm{NH}_{3}\right)_{4} \mathrm{Cl}_{2} \mathrm{Pd}\left(\mathrm{H}_{2} \mathrm{O}\right)$ in the presence of one equiv. of cetylpyridinium $(\mathrm{CPCl})$ as a stabilizing agent upon $\gamma$-irradiation, a very efficient technique to synthesize nanoparticles of controlled size and shape (Fig. 1A). ${ }^{27}$ Although palladium-containing NPs have previously shown satisfactory cellular compatibility, ${ }^{28}$ the presence of $\mathrm{CPCl}$ surfactant in the present nanostructure required careful examination. We, indeed, observed that this formulation was cytotoxic on human primary thyroid cells isolated from histologically non-tumor tissue and on macrophage Raw 264.7 cell line with $\mathrm{IC}_{50}<20-50 \mu \mathrm{M}$ after $24 \mathrm{~h}$ incubation time (Table 1 and Fig. 1C and 1D). Attempts to decrease the toxicity by reducing the amount of $\mathrm{CPCl}$ either in the preparation steps or by post-synthetic dialysis were fruitless (see $\mathrm{ESI}, \dagger$ Fig. S1). Replacement of $\mathrm{CPCl}$ by another surfactant was therefore investigated. In this instance, we turned our attention to the use of polyvinylpyrrolidone (PVP) as it was reported to give stable Pd NPs upon reduction of $\mathrm{Pd}(\mathrm{II})$ salt by ultrasonic irradiation. Moreover, palladium-PVP stabilized NPs were found to catalyze Suzuki-Miyaura cross-coupling reactions in water. ${ }^{29,30}$ In the event, it was discovered that $\gamma$-irradiation of an aqueous solution of $\left(\mathrm{NH}_{3}\right)_{4} \mathrm{Cl}_{2} \mathrm{Pd}\left(\mathrm{H}_{2} \mathrm{O}\right)$ in the presence of $1 \mathrm{~mol} \%$ of PVP provided highly stable nanosuspension of $\mathrm{Pd}$ NPs with narrow size distribution around $70 \mathrm{~nm}$ (DLS). Transmission electron microscopy (TEM) imaging showed nanobead-like structures with average particle size around $50 \mathrm{~nm}$ (Fig. 1B, ESI, †S2). Although these objects no longer displayed the urchin-shape structure, TEM images suggested that they were constituted of nanocrystalline Pd embedded in the polymer. Interestingly, biological evaluation revealed very low cytotoxicity on both Raw 264.7 macrophages and primary culture of human thyrocytes directly arising from patient tissue $\left(\mathrm{IC}_{50}>1 \mathrm{mM}\right)$ (Table 1). Then, the catalytic activity of the two Pd nanoformulation was evaluated on the Suzuki-Miyaura cross-coupling reaction of $\mathrm{N}$ Boc-4-iodo-phenylalanine or $\mathrm{N}$-Boc-4-iodo-thyrosine in $\mathrm{pH} 8$ phosphate buffer using $1 \%$ of Pd Nano catalyst (Scheme 1). In line with our previous findings, it was found that aryl cyclic triolborate potassium salts are better partners than boronic acids for the C-C bond forming reaction catalyzed by $\mathrm{Pd} \mathrm{NPs.}{ }^{24}$ Phenyl cyclic triolborate potassium salt was thus selected as nucleophilic species. Impressively, a full conversion was observed by ${ }^{1} \mathrm{H}$ NMR after only 2 $\mathrm{h}$ incubation at $37^{\circ} \mathrm{C}$ with all nanoformulations. (Table 2, Table S1, Fig. S2).

Table 1. Size, surface charge (Zeta potential) and cytotoxic activity of Pd NPs

\begin{tabular}{ccccc}
\hline NPs & $\begin{array}{c}\text { Size } \\
(\mathrm{nm})\end{array}$ & $\begin{array}{c}\zeta \text {-Potential } \\
(\mathrm{mV})\end{array}$ & $\begin{array}{c}\mathrm{IC}_{50}(\mu \mathrm{M}) \\
(\text { Raw })\end{array}$ & $\begin{array}{c}\mathrm{IC}_{50}(\mu \mathrm{M}) \\
(\text { Thyrocytes })\end{array}$ \\
\hline $\mathrm{CPCl}: \mathrm{Pd} ;$ & 47.6 & +19.7 & 10 & 48 \\
$\mathrm{PVP}: \mathrm{Pd} ;$ & 70.0 & +2.9 & $>1000$ & $>1000$ \\
\hline
\end{tabular}

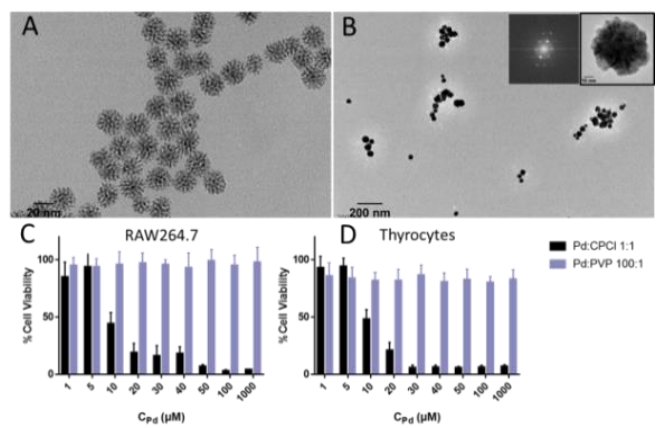

Fig. 1 (A) TEM images of CPCl/Pd 1:1, (B) TEM images of PVP:Pd 1:100; (C) Cell viability of Pd NPs on Raw 264.7. (D) Cell viability of Pd NPs on primary culture of human thyrocytes from patient tissue after $24 \mathrm{~h}$ incubation.

Moreover, the reaction was also tested at $\mathrm{pH} 6$ and $\mathrm{pH} 7$ to make sure that the reaction was not limited to basic media and susceptible to proceed even under slightly acidic conditions such as can be found in some subcellular compartments (i.e. late endosomes and lysosomes). When the reaction was catalyzed by urchin-shape CPCl:Pd; $1: 1 \mathrm{NPs}$ at the lower $\mathrm{pH}$, the conversion rate of the starting material was affected, whereas no influence of the $\mathrm{pH}$ was detected when the crosscoupling was catalyzed by PVP-Pd NPs (Table 2, Table S1). According to these results, all further experiments were conducted with the PVP:Pd 1:100 catalyst. To investigate the catalytic activity of the Pd NPs on a biological macromolecule, the direct arylation of the naturally iodinated bovine thyroglobulin ( $\mathrm{Tg}$ ) was tested (Scheme 2). This commercially available $640 \mathrm{kD}$ dimeric glycoprotein ${ }^{31}$ was found to possess thirty five iodinated tyrosine residues in the form of iodotyrosine (mono- or diiodotyrosine) and iodothyronine (3,5,3'-triiodothyronine or 3,5,3',5'-tetraiodothyronine) as evidenced by MS/MS analysis after 1D SDS-PAGE separation and chymotrypsin digestion of the Tg containing band (Fig. S4, Table S2). ${ }^{32}$

Table 2. Suzuki-Miyaura cross-coupling reactions in water between iodinated amino acids and phenyl boronic acid derivatives catalyzed by Pd NPs at different $\mathrm{pH}$

\begin{tabular}{cccccc}
\hline $\mathrm{N}^{\circ}$ & Catalyst & $\mathrm{Rl}$ & Organoboron & $\mathrm{pH}$ & \% Conv $^{\mathrm{a}}$ \\
\hline 1 & $\mathrm{CPCl}: \mathrm{Pd} ; 1: 1$ & $\mathbf{1}$ & $\mathbf{3}$ & 8.0 & 48 \\
2 & $\mathrm{CPCl}: \mathrm{Pd} ; 1: 1$ & $\mathbf{2}$ & $\mathbf{3}$ & 8.0 & 70 \\
3 & $\mathrm{CPCl}: \mathrm{Pd} ; 1: 1$ & $\mathbf{2}$ & $\mathbf{4}$ & 8.0 & 90 \\
7 & $\mathrm{PVP}: \mathrm{Pd} ; 1: 100$ & $\mathbf{1}$ & $\mathbf{4}$ & 8.0 & 98 \\
8 & $\mathrm{PVP}: \mathrm{Pd} ; 1: 100$ & $\mathbf{1}$ & $\mathbf{4}$ & 7.0 & 98 \\
9 & $\mathrm{PVP}: \mathrm{Pd} ; 1: 100$ & $\mathbf{1}$ & $\mathbf{4}$ & 6.0 & 98 \\
\hline
\end{tabular}

1 equiv. R-I, 3 equiv. R-B(OR) $)_{3} 1$ mol\% Pd NPs, PBS, $37{ }^{\circ} \mathrm{C}, 2$ h. ${ }^{a}$ Conversions were determined by ${ }^{1} \mathrm{H}$ NMR spectroscopy on the crude reaction mixture analyzing the $\mathrm{C}-3$ methylene signal of the $\mathrm{N}$-Boc amino-acids (Fig. S2,S3) 


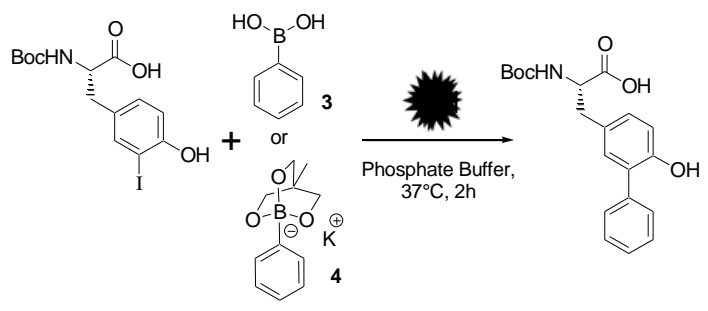

Scheme 1 Suzuki-Miyaura coupling reactions catalyzed by Pd NPs with iodinated amino acids in phosphate buffer

The detection of small chemical modifications within such a large protein involving heterogeneous post-translational iodination represented therefore a major challenge. Proteomic analysis was first used to address a qualitative evaluation of the cross-coupling reaction with phenylboronate. The detection of specific modified tyrosines was achieved by mass spectrometry after Collision-Induced Dissociation (CID)fragmentation $^{33}$ using a LTQ-Orbitrap followed by studies of the fragmentation pathways of protonated peptides providing inter alias C-terminal ammonium $y$ ion series and $\mathrm{N}$-terminal $b$ acylium ion series as previously reported by Dedieu. ${ }^{34}$ The obtained fragments were identified by $\mathrm{X}$ !TandemPipeline (software version 0.2 .24$)^{35}$ by comparison with protein sequence P01267 from Uniprot database. A total of 17 tyrosines modified with one or two phenyl residues were detected on the $\mathrm{Tg}$ (about 50\% of the total iodinated tyrosines) after $24 \mathrm{~h}$ incubation in the presence of PVP-Pd NPs and potassium phenyl cyclic triolborate (Table S2, Fig. S5). This result established the covalent $\mathrm{C}-\mathrm{C}$ binding between the phenyl residue and the native iodinated protein through $\mathrm{Pd}$ nanoobject. To further validate the ability of PVP-Pd NPs to achieve $\mathrm{C}-\mathrm{C}$ bond formation with proteins and to avoid any non-specific reaction, an immunodetection assay was set out. Because streptavidin conjugated to horse-radish peroxidase is commonly used as a standard for immunoblotting protein detection, a biotinylated probe was designed and synthesized. This probe was obtained by coupling a biotin head to a reactive aryl cyclic triolborate through an ethylenedioxy linker, in order to allow detection with streptavidin. Briefly, as depicted in Scheme 3, biotin was first conjugated to a short $\omega, \omega$-diaminotriethyleneglycol spacer to provide the known biotin amide derivative. ${ }^{36}$ Condensation of the latter with 4carboxyphenyl pinacol boronic ester and transesterification with 2-(hydroxymethyl)-2-methylpropane-1,3-diol in the presence of $\mathrm{KOH}$ provided the required biotin cyclic triolborate probe. With the biotin probe in hand, the stage was set for exploring the coupling reaction with the $\mathrm{Tg}$.

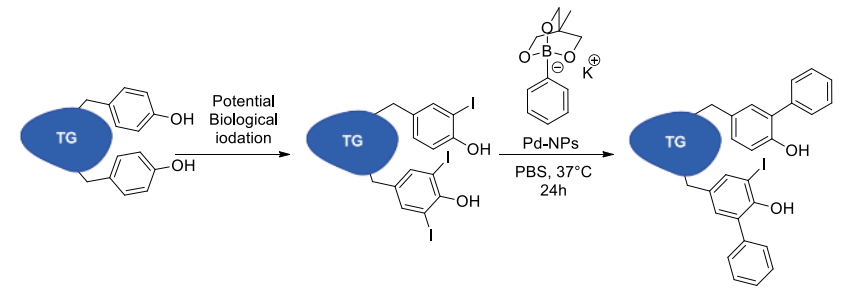

Scheme 2 Suzuki-Miyaura cross-coupling reactions on iodinated Tg catalyzed by Pd NPs

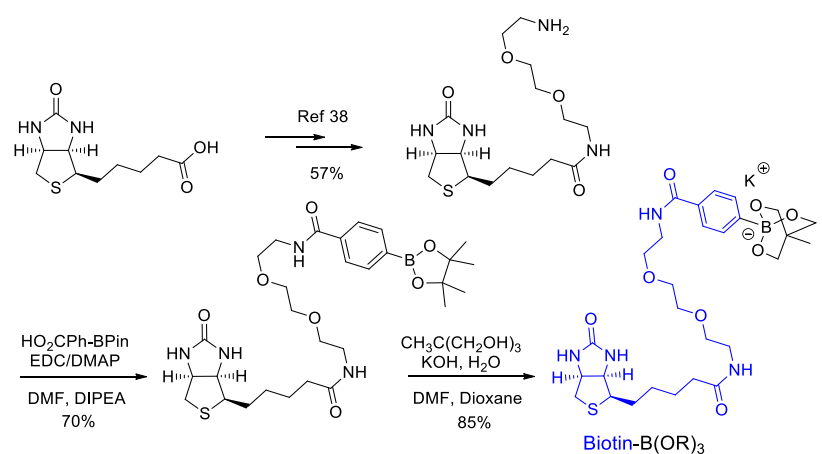

Scheme 3 Synthetic route of the biotin cyclic triolborate probe.

After $24 \mathrm{~h}$ incubation of the bovine $\mathrm{Tg}$ with the biotinylated probe in the presence of 50 equiv. of PVP-Pd NPs, immunoblotting analysis showed fluorescence around 300 $\mathrm{kDa}$, corresponding to $\mathrm{Tg}$, whereas nothing was detected in the control experiments without Pd NPs or without the biotinylated probe (Fig. S10). This result confirmed the $\mathrm{C}-\mathrm{C}$ bond formation but more notably established the absence of non-specific labeling due to the eventual formation of protein-boronate adducts. ${ }^{37,38}$ Having secured an easily detectable coupling partner capable to modify $\mathrm{Tg}$ via Suzuki-Miyaura cross-coupling, we integrated the possibility to perform the bioorthogonal ligation in a complex biological mixture. In vivo, $\mathrm{Tg}$ is iodinated within the follicles in thyroid gland at the thyrocyte surface. ${ }^{39}$ Noteworthy, simple 2D cell culture of thyrocytes provided only un-iodinated Tg not suitable for our study and, in addition, the expression of $\mathrm{Tg}$ rapidly declined after few passage numbers. Commercially available FRTL and FRTL-5 cell lines derived from the thyroid gland of Fisher rats were initially investigated to access iodinated Tg. However, it was found that these cell lines either didn't express $\mathrm{Tg}$ or produced un-iodinated $\mathrm{Tg}$ (Table S3 and Fig. S11). Therefore, in quest for a pertinent model for the cross-coupling reaction on a naturally iodinated protein, it was decided to carry out this reaction into tissue homogenates arising from thyroid biopsies obtained from thyroidectomy on Grave's disease patients. Tg concentration in the homogenate was estimated to be $7.4 \pm 0.4 \mathrm{mg} / \mathrm{mL}$ by ELISA (ESI, $\uparrow \mathrm{S} 8$ ). Incubation of phenyl cyclic triolborate in the tissue homogenate in the presence of $1 \mathrm{~mol} \%$ of PVP-Pd NPs followed by proteomic analysis of the extracted $\mathrm{Tg}$ indicated that iodinated thyrosine residues were covalently modified (Table S4). We next tested the performance of the system to tag the human $\mathrm{Tg}$ with the biotinylated probe. In the event, after $24 \mathrm{~h}$ incubation with PVP-Pd NPs and protein separation by SDS-PAGE gel, immunoblotting analysis showed a bright fluorescent band at $\mathrm{Tg}$ molecular weight that provided evidence of the covalent coupling. The absence of fluorescence in all the control experiments confirmed the full chemoselectivity of the process (Fig. 2D, Fig. S 12).

In summary, we have found that the Suzuki-Miyaura cross-coupling reaction of aryl cyclic triolborate salts catalyzed by Pd NPs allowed a selective modification of a naturally iodinated protein in near intraorgan medium. Coupling was observed with simple aromatic rings but also with a more complex biotinylated probe by westernblotting. 


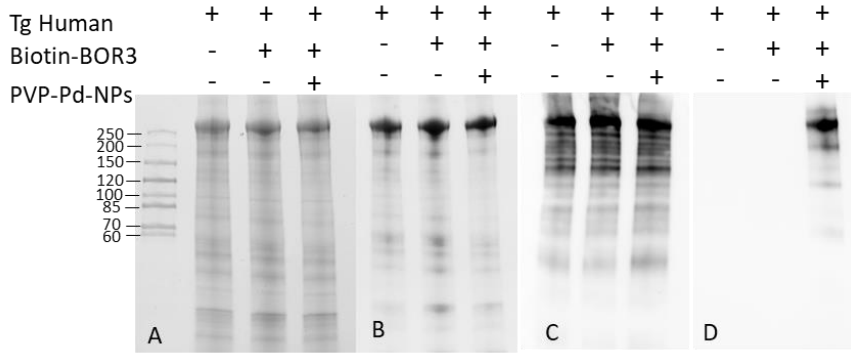

Fig. 2 (A) Separation of homogenate proteins by 1D-SDS Page gel (Stain free image), (B) Stain free image after protein transfer, (C) Detection of Human Thyroglobulin on nitrocellulose membrane was probed with goat anti-human thyroglobulin monoclonal Antibody followed by horseradish peroxidase (HRP)-conjugated anti-goat secondary antibody. The specific band was detected for Thyroglobulin around $300 \mathrm{kDa}$. (D) Detection of $\mathrm{Tg}$ modification on nitrocellulose membrane probe with streptavidin-HRP.

Combined with the low cytotoxicity of the PVP-Pd NPs, this new tool may provide a unique example of specific transitionmetal mediated reactions in a complex and natural biological medium that does not require genetic modification. This opens up the possibility to post-transcriptionally control the levels of thyroglobulin and thyroid hormones by attaching a tag able to recruit the cellular machinery to induce protein degradation. ${ }^{41}$ Given the large number of pathologies associated with the dysregulation of thyroid hormones, such palladium-driven proteolysis-targeting chimeras approach may constitute a new therapeutic tool. The transfer of this approach to now routinely used genetically-encoded iodinated unnatural amino acids could also open new perspectives to dissect and manipulate cellular processes. ${ }^{40}$

The authors thank the Ministère de la Recherche et de la Technologie (Fellowship to A.P.), the Fondation pour la Recherche Médicale (FRM 2018 Fellowship to A.P.), the ANR for Labex NanoSaclay, ANR-10-LABX-0035 grant, the Swiss National Science Foundation (fellowship to A.D.), P. Beaunier from the Laboratoire de Réactivité de Surface, (UMR CNRS 7197, Sorbonne Université, F-75005) for the TEM images and https://smart.servier.com/ for the cartoon used in this publication.

\section{Conflicts of interest}

There are no conflicts to declare.

\section{Notes and references}

1 E. M. Sletten, C. R. Bertozzi, Angew. Chem. Int. Ed. 2009, 48, 6974.

2 M. Grammel, H. C. Hang, Nat. Chem. Biol. 2013, 9, 475.

3 H.-W. Shih, D. N. Kamber, J. A. Prescher, Curr. Opin. Chem. Biol. 2014, 21, 103.

4 M. Yang, J. Li, P. R. Chen, Chem. Soc. Rev. 2014, 43, 6511.

5 O. Boutureira, G. J. L. Bernardes, Chem. Rev. 2015, 115, 2174.

6 V. Hong, S. I. Presolski, C. Ma, M. G. Finn, Angew. Chem. Int. Ed. 2009, 48, 9879.
7 J. M. Baskin, J. A. Prescher, S. T. Laughlin, N. J. Agard, P. V. Chang, I. A. Miller, A. Lo, J. A. Codelli, C. R. Bertozzi, Proc. Natl. Acad. Sci. U.S.A. 2007, 104, 16793.

8 M. F. Debets, S. S. Van Berkel, J. Dommerholt, A. J. Dirks, F. P. J. T. Rutjes, F. L. Van Delft, Acc. Chem. Res. 2011, 44, 805.

9 D. K. Kömel, E. T. Kool, Chem. Rev. 2017, 117, 10358-10376

10 D. S. Liu, A. Tangpeerachaikul, R. Selvaraj, M. T. Taylor, J. M. Fox, A. Y. Ting, J. Am. Chem. Soc. 2012, 134, 792.

11 J. W. Wollack, B. J. Monson, J. K. Dozier, J. J. Dalluge, K. Poss, S. A. Hilderbrand, M. D. Distefano, Chem. Biol. Drug Des. 2014, 84, 140.

12 S. Eising, N. G. A. van der Linden, F. Kleinpenning, K. M. Bonger, Bioconjug. Chem. 2018, 29, 982.

13 Y. Gong, L. Pan, Tetrahedron Lett. 2015, 56, 2123.

14 J. M. Antos, M. B. Francis, Curr. Opin. Chem. Biol. 2006, 10, 253.

15 K. Tsubokura, K. K. H. Vong, A. R. Pradipta, A. Ogura, S. Urano, T. Tahara, S. Nozaki, H. Onoe, Y. Nakao, R. Sibgatullina, A. Kurbangalieva, Y. Watanabe, K. Tanaka, Angew. Chem. Int. Ed. 2017, 56, 3579.

16 A. M. Pérez-López, B. Rubio-Ruiz, V. Sebastián, L. Hamilton, C. Adam, T. L. Bray, S. Irusta, P. M. Brennan, G. C. LloydJones, D. Sieger,J. Santamaria, A. Unciti-Broceta, Angew. Chem. Int. Ed. 2017, 56, 12548.

17 K. K. Sadhu, E. Lindberg, N. Winssinger, Chem. Commun. 2015, 51, 16664.

18 R. M. Yusop, A. Unciti-Broceta, E. M. V. Johansson, R. M. Sánchez-Martín, M. Bradley, Nat. Chem. 2011, 3, 239.

19 J. Li, J. Yu, J. Zhao, J. Wang, S. Zheng, S. Lin, L. Chen, M. Yang, S. Jia, X. Zhang, P. R. Chen, Nat. Chem. 2014, 6, 352.

20 A. Dumas, P. Couvreur, Chem. Sci. 2015, 6, 2153

21 C. D. Spicer, T. Triemer, B. G. Davis, J. Am. Chem. Soc. 2012, $134,800$.

22 J. Li, S. Lin, J. Wang, S. Jia, M. Yang, Z. Hao, X. Zhang, P. R. Chen, J. Am. Chem. Soc. 2013, 135, 7330.

23 M. A. Miller, B. Askevold, H. Mikula, R. H. Kohler, D. Pirovich, R. Weissleder, Nat. Commun. 2017, 8, DOI 10.1038/ncomms15906.

24 A. Dumas, A. Peramo, D. Desmaële, P. Couvreur, Chimia 2016, 70, 252.

25 H. K. Makadia, S. J. Siegel, Polymers (Basel). 2011, 3, 1377.

26 F. Ksar, G. K. Sharma, F. Audonnet, P. Beaunier, H. Remita, Nanotechnology 2011, 22, DOI 10.1088/09574484/22/30/305609.

27 J. Belloni, M. Mostafavi, H. Remita, J.-L. Marignier, M.-O. Delcourt, New J. Chem. 1998. 22, 1239.

28 S. V. Chankeshwara, E. Indrigo, M. Bradley, Curr. Opin. Chem. Biol. 2014, 21, 128.

29 A. Nemamcha, H. Moumeni, J. L. Rehspringer, Phys. Procedia 2009, 2, 713.

30 Y. Li, E. Boone, M. A. El-Sayed, Langmuir 2002, 18, 4921.

31 Y. Noguchi, N. Harii, C. Giuliani, I. Tatsuno, K. Suzuki, L. D. Kohn, Biochem. Biophys. Res. Commun. 2010, 391, 890.

32 F. Gentile, V. Pansini, Eur. J. Biochem. 1993, 621, 603.

33 F. Gentile, P. Ferranti, G. Mamone, A. Malorni, G. Salvatore, J. Biol. Chem. 2002, 272, 639.

34 A. Dedieu, J. C. Gaillard, T. Pourcher, E. Darrouzet, J. Armengaud, J. Biol. Chem. 2011, 286, 259.

35 R. Craig, R. C. Beavis, Bioinformatics 2004, 20, 1466.

36 J. A. Stewart, B. F. Piligian, S. R. Rundell, B. M. Swarts, Chem. Commun. 2015, 51, 17600.

37 H. Li, Z. Liu, Trends Anal. Chem. 2012, 37, 148.

38 A. M. Azevedo, A. G. Gomes, L. Borlido, I. F. S. Santos, D. M. F. Prazeres, M. R. Aires-Barros, J. Mol. Recognit. 2010, 23, 569.

39 D. P. Carvalho, C. Dupuy, Mol. Cell. Endocrinol. 2017, 458, 6.

40 S. V. Sharma, X. Tong, C. Pubill-Ulldemolins, C. Cartmell, E. J. A. Bogosyan, E. J. Rackham, E. Marelli, R. B. Hamed, R. J. M. 
Goss, Nat. Commun. 2017, 8, DOI 10.1038/s41467-017-

00194-3

41 H. Peia, Y. Peng, Q. Zhao, Y. Chen RSC Adv. 2019 ,9, 1696716976 